\title{
Natural rates in the New Synthesis: Same old trouble?
}

\author{
Hans-Michael Trautwein ${ }^{*}$ and Abdallah Zouache ${ }^{* *}$
}

\begin{abstract}
This paper evaluates the concepts of natural rates of interest and output in Woodford's "neo-Wicksellian" and "benchmark New Keynesian"version of the New Neoclassical Synthesis (NNS) by comparing them with the original approach of Wicksell and critical assessments and adaptations by Lindahl, Myrdal, Keynes and Friedman. It is shown that the theoretical foundations of the NNS prescriptions for monetary policy are ambiguous and incomplete. Using the NNS definition(s) of the natural rate of output, New Keynesian policy rules do not necessarily yield results superior to those of "Old Keynesian " strategies of output stabilization. Moreover, natural rates of interest can hardly be defined independently of the influences of monetary policy. The use of natural-rate concepts in the NNS disregards essential problems that were identified in the older Wicksellian and Keynesian literature.
\end{abstract}

JEL classifications: EIo, E30, E50

Keywords: natural rate, output gaps, interest-rate gaps, Wicksellian theory

\section{Introduction}

Since the beginnings of modern macroeconomics, natural rates have been used as benchmarks in various contexts. The "natural rate of interest «, the "natural rate of growth", and the "natural rate of unemployment " are all familiar concepts that have served as equilibrium references of different kinds. They have been defined (I) as hypothetical notions for the

* Carl von Ossietzky University Oldenburg, Germany.

** CREUSET - CNRS, Université Jean Monnet, Saint Etienne, France.

Correspondence Address:

Hans-Michael Trautwein, FK II - VWL, Carl von Ossietzky Universität Oldenburg, 26III Oldenburg, Germany, e-mail: michael.trautwein@uni-oldenburg.de.

Received 02 February 2009, accepted 29 March 2009

(C) INTERVENTION 6 (2), 2009, 207-225 
measurement of gaps between the actual and optimal levels, or steady-state value, of the variable in question, (2) as attractors, on which the market system tends to converge (if undisturbed), and/or (3) as normative guidance for policy rules.

In all three functions, concepts of natural rates have met much criticism, especially from the Keynesian camp. Nonetheless, they play a key role in the current consensus view, the "New Neoclassical Synthesis" (henceforth: NNS). Describing elements of that synthesis, Michael Woodford argues in his recent paper on Convergence in Macroeconomics (2009: 69) that it »is now widely agreed that macroeconomic analysis should employ models with coherent intertemporal general-equilibrium foundations " (emphasis in the original). Business cycles and growth are analyzed within a single framework that is based on Walrasian principles. Woodford emphasizes that

"this does not mean that the Keynesian goal of structural modeling of short-run aggregate dynamics has been abandoned. Instead, it is now understood how one can construct and analyze dynamic general-equilibrium models that incorporate a variety of types of adjustment frictions, that allow these models to provide fairly realistic representations of both shorter-run and longer-run responses to economic disturbances« (ibidem).

More specifically, the

"dynamic stochastic general equilibrium (DSGE) models now used to analyze the short-run effects of alternative policies often involve imperfect competition in both labor markets and product markets« (ibidem).

The new synthesis thus combines the New Classical DSGE technology of Real Business Cycle (RBC) theory with New Keynesian emphasis on nominal and real rigidities in the price mechanism.

Woodford is also the author of Interest and Prices (2003), a landmark contribution to the NNS, in which he stresses the importance of natural rates of interest and output for modeling macroeconomic dynamics in the short run. In addition to the benchmark role of the natural rate of interest in understanding how a given kind of interest-rate policy will affect inflation determination" (Woodford 2006: 17), the corresponding concept of the natural rate of output permits to make use of welfare analysis to provide normative guidance for monetary policy. The two natural rates serve to identify, quantify and eliminate what are believed to be inefficient outcomes of the market interaction of households, firms and the central bank. The general conclusion is that the elimination of inflation by way of rule-bound interest-rate policy will let the system converge on its natural rates of interest and output, the steady-state rates of the long run, and thereby minimize the welfare losses of the short run.

Woodford's focus on natural rates makes his version of the NNS more encompassing than the standard combination of RBC with New Keynesian theory (Goodfriend 2002), in that it includes core elements of pre-Lucasian macroeconomics. Woodford (2003: 5-8) refers explicitly back to Friedman's natural rate of unemployment and, most fervently, to 
Wicksell's natural rate of interest, claiming to have reformulated Wicksellian insights in terms of a theory that meets "modern standards of conceptual rigor». Moreover, the natural rates in Woodford's framework may be interpreted as nesting concepts of "potential output " and the "neutral rate of interest " that have also been used in the Keynesian literature (following Keynes I936: 243 and Okun 1962). The new synthesis thus gives the impression of being a general theory.

However, natural rates are also a contentious issue in the NNS. A burgeoning literature is exploring the implications of model uncertainty and measurement uncertainty about the natural rate of interest (see, e.g., Laubach/Williams 2003, Tristani 2007, Weber et al. 2008). The former refers to misspecification of variables, time structures, shocks and other model ingredients, whereas the latter concerns the data and estimation problems connected with a benchmark rate that is not (directly) observable. While there is a wide array of positions on these matters, there is (so far) little dispute about the analytical foundations of the natural rates of output and interest in terms of the underlying general equilibrium theory.

There was much less consensus in earlier macroeconomics. Discussions about natural rates of interest and unemployment were closely connected with controversies about the long-run neutrality of money, nowadays (almost) a non-issue in the NNS. The core question was, whether any equilibrium rate could be consistently defined independently of monetary policy. Keynes and the old Keynesians took a critical view of the neutrality proposition, and so did Lindahl, Myrdal and other followers of Wicksell, to whom Woodford (2003: 5 - 8) refers as precursors. This raises the question, whether Woodford's version of the new synthesis - which he calls "neo-Wicksellian « and which is also labeled as »the benchmark New Keynesian model« (e.g., De Fiore/Tristani 2008) - really makes for an encompassing and consistent framework.

In this paper, we examine Woodford's concepts of natural rates of output and interest in the light of earlier debates. We draw attention to ambiguities that can be made visible with reference to Wicksellian, Keynesian and even Friedmanite notions of "natural «, "normal« and »neutral rates". These ambiguities are related to analytical restrictions that result from modeling suboptimal market outcomes in the framework of intertemporal general equilibrium, or DSGE. They concern ( $i$ ) the notion of a natural rate of output under imperfect competition and inherent problems of using it as benchmark for monetary policy, and (ii) the difficulties of defining a natural rate of interest that is completely independent of monetary policy.

We are not the first to evaluate the concepts of the natural rate of interest in the Wicksellian, Keynesian and NNS literatures (see Amato 2005, van der Ploeg 2005, and Weber et al. 2008). Yet, our paper makes two extensions of that literature. After providing an outline of the canonical NNS model and its notions of natural rates in the following section, we discuss, in Section 3, the normative content of the NNS concept of the natural rate of output against the background of Friedman's natural rate of unemployment and Okun's notion of potential output. We show that - based on the output benchmark as such and evaluated by the internal standard of intertemporal general equilibrium - an interest-rate policy that follows Woodford's prescription is not necessarily preferable to an output-stabi- 
lizing policy along older Keynesian lines. In Section 4, we explore different meanings of the concept of a natural rate of interest as developed (and mostly relabeled as normal or neutral rates) in Wicksellian and Keynesian macroeconomics. As that concept was developed in the context of intertemporal disequilibrium, we thus shift to an external standard of evaluation. Drawing on insights of Lindahl, Myrdal and Keynes, we set the focus on Woodford's difficulties to consistently define a benchmark rate of interest that would be independent of the influences of monetary policy. Section 5 concludes that there are grave doubts about the usefulness of concepts of natural rates as long-run attractors for the short-run dynamics and as benchmarks for the measurement of gaps and their minimization. In the light of older macroeconomic debates, these analytical foundations of modern macroeconomics look rather shaky.

\section{Woodford's canonical NNS model}

With reference to the IS-LM-AS framework of the old Neoclassical Synthesis, the core model of the New Neoclassical Synthesis can, in shorthand, be characterized as IS-AS-MP. It is a system of three equations that describes the short-run dynamics of output, inflation and interest rates, where the monetary policy equation, MP, specifies the reaction function of the central bank, typically in terms of a Taylor rule for setting interest rates.

Woodford's version of the NNS core model is a log-linear approximation of the conditions for intertemporal general equilibrium under rational expectations (2003: 243-247), here summarized in a slightly simplified fashion. ${ }^{I}$ The IS equation describes a negative relationship between income (aggregate demand) and interest in terms of intertemporal general equilibrium. It is obtained by log-linearizing the first-order condition of the representative household's optimal consumption over time:

$$
x_{t}=E_{t} x_{t+1}-\sigma\left(i_{t}-E_{t} p_{t+1}-r_{t}\right),
$$

where $x$ denotes the gap between actual output and the "natural rate of output (actually their levels in logs), $E_{t} \ldots$ is the operator for rational expectations, $\sigma$ the intertemporal elasticity of substitution, $i$ the nominal interest rate, $p$ the inflation rate, and $r$ the real $»$ natural rate of interest «. Referring to Real Business Cycle theory, Woodford introduces the »natural rate of output" as the

"level of output that would occur in an equilibrium with flexible wages and prices, given current real factors (tastes, technology, government purchases)« (2003: 8).

It is " a sort of virtual equilibrium « whose evolution matters because the gaps between its values and the actual quantities of output are »important measures of the incentives for wage and price adjustment and hence determinants of wage and price dynamics (2003: 9). If the current output gap, $x_{t}$, equals zero, the composite interest term in Equation (I) represents 
the natural rate of interest which is "just the real rate of interest required to keep aggregate demand equal at all times to the natural rate of output « (2003: 248). Woodford's framework is based on forward-looking behavior of the private sector, i.e., the actual output gap is determined by the expected output gap and expected inflation as well as by contemporaneous shocks and policy changes (embedded in $r$ and $i$ ).

The AS equation describes the relationship between aggregate supply and inflation. In the spirit of the new synthesis it is defined as a New Keynesian Phillips curve in which actual inflation equals expected inflation plus the actual output gap:

$$
p_{t}=\beta E_{t} p_{t+1}+\kappa x_{t},
$$

where $\beta$ is a discount factor and $\kappa$ a rigidity parameter. The underlying assumption is that firms act in monopolistic competition and set their prices in a staggered fashion. Whenever shocks occur to the real interest rate (through $i$ or $r$ ), a number of firms will maximize their profits by varying their output rather than prices. If there is a large degree of strategic complementarity between the pricing decisions of different firms (affecting $\kappa$ ), price stickiness will make the effects of shocks to the output gap large and persistent.

The model is closed by the MP equation that describes the reaction function of monetary policy in terms of a Taylor rule:

$$
i_{t}=i^{*}+\gamma_{p}\left(p_{t}-p^{*}\right)+\gamma_{x}\left(x_{t}-x^{*}\right),
$$

where $i^{*}$ corresponds to the nominal value of the natural rate of interest, insofar as it can be observed and controlled by the central bank. The two policy coefficients $y_{p}$ and $y_{x}$ define the relative weights of inflation and output targets and, hence, the relative intensity of interest-rate reactions to the respective gaps. The target value for the output gap is defined as the steady-state value in accordance with the inflation target, $x^{*}=(1-\beta) p^{*} / \kappa$. ${ }^{2}$ This makes the Taylor rule internally consistent, as it ensures that $i$ equals $i^{*}$, whenever the inflation target $p^{*}$ is achieved. Finally, it determines the endogenous variables $i, p$ and $x$ in Equations (I) - (3).

The policy conclusion from Woodford's model is a Taylor rule that sets the inflation target near zero. In this case, price stickiness will not come into effect and output will stay close to its natural rate. Optimal monetary policy thus requires that the nominal rate of interest corresponds to the nominal value of the natural rate of interest. With this prescription, the new synthesis yields neo-Classical results from a model that is labelled (New) Keynesian on the grounds that, as long as the actual rates of interest and output do not correspond to the natural rates, output adjustments precede, or even prevent, price adjustments.

2 As a referee has correctly pointed out, there is a possible source of long-run non-neutrality of monetary policy, since the steady-state output gap is not independent of the choice of inflation target whenever $\beta<1$ (or $>1$ ). Woodford (2003: $244 \mathrm{n}$. I2) acknowledges the possibility of a non-zero gap in the steady state, but ignores such non-neutralities, as he log-linearizes around a zero-inflation steady state. 
"In this way it is established that a nonmonetarist analysis of the effects of monetary policy does not involve any theoretical inconsistency of departure from neoclassical orthodoxy« (2003: 238).

\section{Natural rates and output gaps}

\section{I Following Friedman?}

Woodford's introductory definition of the natural rate of output - as the »level of output that would occur in an equilibrium with flexible wages and prices« (2003: 8) - seems clear and simple. At further reading, however, the implications and variations of that definition become not only more complex (which would be natural), but also more ambiguous (which tends to reduce the concept's usefulness). Woodford's introductory definition (2003: 8) actually foreshadows those conceptual difficulties, since it includes the casual statement that the output level in the virtual flexprice equilibrium is "what is called the snatural rater of output, following Friedman (1968) «. ${ }^{3}$

It is well known that Friedman (I968: 7 - II) coined the phrase "natural rate of unemployment " - with due reference to Wicksell's natural rate of interest; he did not then speak about a natural rate of output, even though that term had already been coined. ${ }^{4}$ Nonetheless, a natural rate of output is implicit in Friedman's 1968 story, insofar as deviations from the natural rate of unemployment come along with (positive or negative) excess demand for goods. In later writings, Friedman more directly addressed the issue of output gaps (e.g., Friedman/Schwartz 1982: 60-65). Yet, in the 1968 paper, Friedman's defining characteristic of the respective natural rate is full expectedness rather than price flexibility, as he sets the focus on the transitory nature of money illusion in the presence of adaptive expectations. And Friedman/Schwartz (1982: 64) point out that the

"transition between the short-run adjustment process and long-run equilibrium is produced by a revision of anticipated values in response to measured values in such a way that, for a stable system, a single disturbance sets up discrepancies that are in the course of time eliminated."

Nonetheless, Friedman's famous 1968 definition of the natural rate of unemployment includes a range of "structural characteristics" that may prevent prices and wages from being fully flexible:

3 A more appropriate reference would have been Patinkin (1965). However, as Patinkin's Money, Interest and Prices made a connection from Wicksell to the "old " neo-Classical Synthesis by way of the real-balance effect (see his Note E), that book is diametrically opposed to Woodford's Interest and Prices, where the real-balance effect is irrelevant, as in Wicksell's pure credit economy.

4 According to Phelps (1995: 16), the concept of a natural rate of output dates back to the works of Abba Lerner in the r940s and William Fellner in the I950s. 
"The snatural rate of unemployment $<[\ldots]$ is the level that would be ground out by the Walrasian system of general equilibrium equations, provided there is imbedded in them the actual structural characteristics of the labor and commodity markets, including market imperfections, stochastic variability in demands and supplies, the cost of gathering information about job vacancies and labor availabilities, the costs of mobility, and so on." (Friedman 1968: 8)

\subsection{Gaps, wedges and welfare}

Whatever one may think about the compatibility of Walrasian general equilibrium theory with market imperfections and other structural characteristics, Woodford (2003) appears to follow that Friedmanite agenda. In his discussions of the concepts of a natural rate of output and output gaps, he reduces Friedman's "structural characteristics" to imperfect competition and corresponding price rigidities. Let us follow the variations step by step.

Step I: perfect competition. A»Walrasian system of general equilibrium equations« is usually taken to describe a model with full price flexibility under perfect competition. In that type of model, which is also underlying New Classical RBC theory, market prices of goods equal their marginal supply cost in equilibrium, and the marginal rates of transformation equal the marginal rates of substitution $(m r t=m r s)$. The natural rate of output would thus be Pareto efficient, and any gap between its level and actual output would be inefficient by definition. In Woodford's baseline model of intertemporal optimization and price-level determination (2003: ch. 2), the Walrasian model of perfect competition is at the back of the definition of the natural rate of output. However, the supply of goods is exogenous.

Step 2: monopolistic competition. In chapter 3, Woodford (2003) endogenizes the supply of goods in a Dixit-Stiglitz-type model of monopolistic competition. This market structure is chosen to facilitate the introduction of nominal rigidities under rational expectations. With price stickiness, output gaps can be described as results of optimal price-setting behavior of the firms. The benchmark for the assessment of such output gaps is derived from a model of monopolistic competition at perfectly flexible prices. Woodford (2003: I5I - I52) calls the solution to the corresponding real marginal-cost function (expressed as a fraction of the desired mark-up) »the natural rate of output « - again "following Friedman (1968)«.5 In this setting, goods prices exceed, on average, their marginal costs, and the marginal rates of substitution differ from the marginal rates of transformation $(m r t<m r s)$. Hence the natural rate of output in the flexprice monopolistic-competition model is not Pareto efficient, but defines an equilibrium output level that is "completely independent of monetary policy" and "a useful summary of the way in which disturbances shift the real marginal cost function, whether prices are constantly adjusted or not« (2003: I52).

5 Equilibrium output is expressed as $Y_{t}=Y^{n}\left(\xi_{t}\right)$, where the RHS term represents the solution to the real marginal-cost equation $s\left(Y_{t}^{n} ; \xi_{t}\right)=\mu^{-1}$, and where $Y_{t}$ is the aggregate output of the diversified goods in period $t, Y^{n}$ the "natural rate of output, $\xi_{t}$ the vector of shocks to tastes and technology, $s$ the real marginal supply cost and $\mu(>1)$ the desired mark-up. 
Step 3: output gaps. The definition of output gaps is then given: If prices are sticky, optimizing price-setters will, to a certain degree, react to shocks by varying their output. Actual output can thus deviate from the natural rate. For analytical convenience, Woodford (2003: 177 - 187) introduces the Calvo model of staggered price-setting where in each period only a fraction of goods prices adjusts to new information, whereas the other prices remain unchanged, and where the "right « to change prices is distributed randomly. If there are shocks to tastes, technology, input prices or fiscal policy that monetary policy does not compensate (so as to preserve price-level stability), staggered price-setting will lead to output gaps. It produces distortions of the price structure that increase in the degree of strategic complementarity of the pricing decisions. Woodford conceptualizes these price distortions and quantity adjustments as deadweight losses that can be analyzed in welfare-theoretical terms $(m r t<m r s)$. It is this kind of inefficiency that Woodford seeks to make amenable to monetary policy. But how is the inefficiency in the output gaps exactly related with the market-power-related inefficiency in the "natural rate«? Let us look at Woodford's distinctions in the next steps.

Step 4: gaps and wedges. In part II of his book, Woodford extends the neo-Wicksellian framework to discuss its welfare-theoretical implications. He begins by analyzing the "consequences of a mildly inefficient natural rate of output « (2003: 4II - 4I6). The "actual natural rate of output « is determined by the degree of market power in the economy as well as its dispersion (by way of strategic complementarity). This "mildly inefficient natural rate" is considered to differ from the efficient "flexible-price limit" (2003: 407 - 4II) by a small constant wedge, a concept that should be distinguished from the variable gap between actual output and the natural rate. ${ }^{6}$ Output gaps thus imply two sorts of inefficiency: the basic inefficiency of imperfect competition plus the welfare cost of a monetary policy that does not react sufficiently to real shocks, or even generates shocks of its own. The important point is that, under Woodford's assumptions, stabilizing the gap between natural and actual output near zero is optimal, because the natural rate output is then a good (log-linear) approximation of the efficient rate of output. This is the base of Woodford's determined advocacy of interest-rate rules that stabilize inflation near zero. It implies that there is no trade-off between inflation stabilization and the stabilization of the output gap, at any rate not in the long run. ${ }^{7}$ Insofar as the output gaps result from nominal rigidities, and the latter can be made ineffective by price-level stabilization, this is plausible. However, the two restrictions "mildly" (inefficient natural rate) and "constant « wedge betray a certain precariousness of the policy conclusions. Both Woodford (2003) and other contributions to the literature (notably Benigno/Woodford 2005, and Blanchard/Galí 2005) have analyzed the implications of these restrictions in greater detail, as will be discussed in the next step.

6 Woodford (2003: 45I) speaks confusingly of „different output-gap concepts«. We describe the distance between the efficient flexible-price limit and the inefficient natural rate of output (where $m r t$ $<m r s)$ as a (non-tax) "wedge«.

7 It should be noted that Woodford (2003: 416 - 419) does not advocate complete price stability. 
Step 5: inflation stabilization and welfare. In order to illustrate the issues at stake we have captured the distinctions between the wedge and the gaps in Figure I, which describes the case of a large, constant wedge. ${ }^{8}$ Blanchard/Galí (2005) show that Woodford's equivalence of stabilizing inflation to maximizing welfare derives from the "divine coincidence" of a constant distance between $Y_{t}^{e}$, the first-best rate of output, and $Y_{t}^{n}$, the second-best. In other words, $Y_{t}^{n}$ is an appropriate $\log$-linear approximation of $Y_{t}^{e}$ only if the wedge remains unchanged. Woodford concedes that the AS relation (Equation 2) fails to provide sufficient information about welfare losses, if the wedge varies over time: It is $Y_{t}-Y_{t}^{n}$ »that is relevant for measuring inflationary pressure in the AS relation", whereas $Y_{t}-Y_{t}^{e} »$ is relevant for the welfare evaluation of alternative equilibria" (2003: 45I - also 6I6, n. 54). Introducing a "cost push « disturbance term in the AS relation, Woodford states "that it is no longer possible to simultaneously stabilize both inflation and the welfare-relevant output gap « (2003: 452). Blanchard/Galí (2005) go even further and argue that the divine coincidence is not simply a matter of absence of shocks to the wedge; it results more generally from the absence of non-trivial real imperfections in Woodford's framework. Introducing real wage rigidities they show that adverse supply shocks interact with the rigidities in such a way that endogenous variations in wage mark-ups give rise to trade-offs between stabilizing inflation and maximizing welfare, which may even be effective in the long run.

Figure I: Woodford's output rates, gaps and wedges

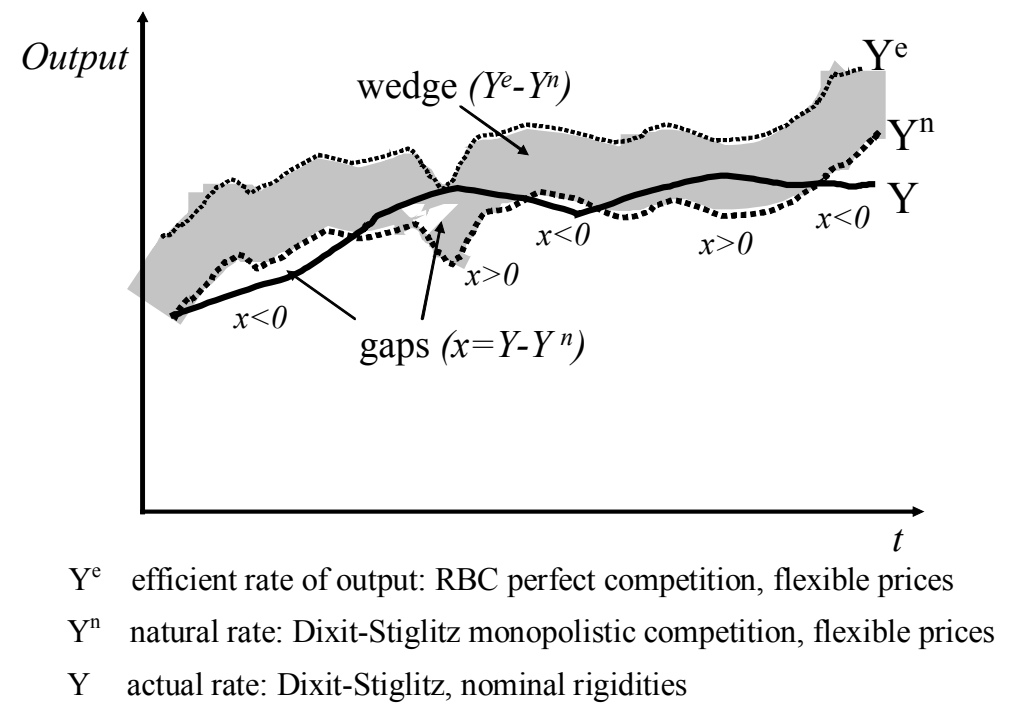

8 This is an intermediate case that Woodford does not discuss. He presents cases in which the wedge is zero or small, but constant (2003: 407-416), or larger and variable (2003: 455-463). 
The other issue is the size of the inefficiencies represented by the wedge, and its relation to the output gaps. As expected utility depends on the expected level of output, the natural rate of output, $Y^{n}$, might not be a good proxy for the welfare-relevant output and hence not useful for deriving the optimal policy rule. In a sophisticated argument Woodford (2003: $455-463$ ) demonstrates nonetheless that, under certain conditions, his conclusions from the case of a "mildly inefficient natural rate of output " survive even in the case of larger distortions (see also Benigno/Woodford 2005): The optimal long-run inflation rate is zero and the optimal monetary policy involves only small deviations from zero. ${ }^{9}$

Yet, the preconditions of this argument are too specific to rule out a further objection that is easy to make out from the figure above. If the wedge is sufficiently large, expansionary output gaps $\left(x_{t}>0\right)$ could reduce the inefficiency implied by the wedge. Can it be excluded that policy strategies which produce such expansionary gaps are pareto-superior or equivalent to strategies that aim at minimizing output gaps? Take, for instance, the typical Keynesian strategies of the I960s and I970s that targeted potential output, as defined by Okun (1962). Okun's concept can be interpreted as consistent with Woodford's natural rate of output, insofar as it defined (i) potential output as the macroeconomic output level associated with neither inflationary pressure nor unemployment, and (ii) the corresponding growth rate as equivalent to the natural growth rate. ${ }^{\text {IO }}$ Yet, Okun's characterization of output gaps as cyclical deviations from the growth trend also fostered the application of statistical methods in policies that would attempt to keep actual output relatively close to the trend. Now, assume that the time path of the actual rate of output, $Y$, in the figure above represents the realization of such an output-smoothing strategy, which in comparison with the NNS Taylor rule (Equation (3) of Section 2) could be expressed as:

$$
i_{t}=i_{t-1}+\gamma_{x}\left(x_{t-1}-\bar{x}_{t}\right) \text {, }
$$

where $\bar{x}$ represents the trend rate of output growth, as perceived in $t$. Can it be excluded that this strategy is pareto-superior to one that minimizes output gaps with regard to the time path of $Y^{n}$ ? Woodford (2003) fails to exclude this possibility; he does not even discuss it, because it seems to be precluded by various assumptions underlying the NNS framework, such as rational expectations of the private sector and the (implicit) continuous equilibrium of savings and investment. ${ }^{\text {II }}$ Both assumptions bring us to the confrontation of Woodford's concept of the natural rate of interest with earlier debates about that notion.

9 Technically speaking, Woodford (2003: 455-463) and Benigno/Woodford (2005) derive a quadratic approximation to the utility-based welfare-loss function. The minimization of this function can be formulated as the policy problem to be solved, subject to the constraint that the AS relation of equation (2), which is augmented with a cost-push disturbance term, holds each period.

Io Even though Okun (1962 [1983: 146 - I58]) stressed the difficulties of measuring the "potential labor force«, he made it clear that - given the NAIRU (in his case: a four percent unemployment rate) as "target rate of labor utilization" - in his concept, changes in potential output (or GNP) are directly correlated with changes in the effective labour supply.

II Benigno/Woodford (2005) discuss the case of randomized monetary policy. They show that this strategy of producing output gaps (positive and negative) by confusing the private sector would be 


\section{The natural rate of interest}

\section{I Differing Wicksell connections}

A central difference between the New Keynesians of the NNS and Keynes himself is the role played by wage and price stickiness in the explanation of output fluctuations. While such nominal rigidities are crucial for New Keynesians, Keynes (1936: ch. 19) stressed that they are not essential. Wage and price flexibility would not provide a cure for effective demand failures which keep output at levels that generate involuntary unemployment. On the contrary, nominal and real wage adjustments tend to make things worse. As Leijonhufvud (I98I) has pointed out, Keynes had a "Wicksell Connection« in the underlying argument that coordination failures of interest rates, i.e. the intertemporal price mechanism in the capital market, result in excess demands (positive or negative) in goods and/or labor markets, and that those excess demands are not automatically cured by price or wage adjustments in those other markets.

In Wicksell (I898: 94- IOI), the excess demands, which arise from differences between the market rate of interest and the natural rate, translate into changes in the price level only. These changes might eventually feed back to the market rate of interest and close the gap, but they would not be reversed automatically; the price level at the end of the cumulative process would be different from the original one. In the Wicksellian literature of the inter-war area, Wicksell's separation of cumulative processes and business cycles was abandoned, and interest-rate gaps were discussed as causes of changes in the structures and levels of prices and production. Wage stickiness did play a role in some of the transmission stories, in terms of differences in the speed of price and wage adjustments; but the major matter of contention was the effect that cumulative price changes could have on the capital stock. If misalignments of the market rate of interest lead to changes in marginal productivity, can the (expected) rate of return on real investment still be considered a $»$ natural rate of interest" on which the system would converge? Would monetary policy have the power to generate and to prevent cyclical, or even sustainable, changes in the structures of prices and production? These were the questions raised by Lindahl (1930), Myrdal (1931), Hayek (I93I) as well as Keynes (1930), before his General Theory of 1936.

Since Woodford (2003) approvingly refers to Lindahl, Myrdal and Hayek, while his DSGE-based approach fundamentally differs from their disequilibrium frameworks, it is instructive to compare and contrast his notion of the natural rate of interest with theirs. Furthermore, as we will see, Keynes's critique of the concept of a natural rate of interest in his General Theory (1936) adds to the contrast. For the comparisons in the following subsections, it is helpful to make a distinction between different causes of suboptimal states of the economy, which has also been developed by Leijonhufvud (I98I). Output gaps may be explained in terms of some "spanner in the works" malfunction of the price mechanism,

compatible with the NNS framework under certain conditions, but argue that it is of little practical interest. Yet, randomized monetary policy should not be confused with discretionary monetary policy or (non-contingent) rules that include "output-smoothing", as discussed above. 
"for which we may imagine that agents actually do have full information (so that all the nuts and bolts of standard theory can be used) but are prevented from acting on what they know" (Leijonhufvud I98I: I40).

Or they may be explained by incomplete information states of the system, which materialize in failures of interest rates to achieve optimal coordination of intertemporal plans of consumption and production. Incomplete information can lead to mutually inconsistent beliefs and corresponding disequilibria, or to mutually consistent, but incorrect beliefs that may produce temporary equilibria. The disequilibrium approach was used by Wicksell (I898), Lindahl (1930), Myrdal (I93I), Hayek (193I) and Keynes (1930), whereas the temporary-equilibrium approach was chosen by Keynes (1936) as well as various brands of Keynesianism. Woodford (2003: 5) links his contribution to the NNS to Wicksell, Lindahl and Myrdal, but employs - like most New Keynesians - the "spanner in the works" approach by combining imperfect competition with nominal rigidities (as discussed in Section 3). In some parts of the NNS literature, price stickiness is introduced through qualifications of the rational-expectations hypothesis, blending the "spanners in the work" approach with aspects of "incomplete information ${ }^{12}{ }^{12}$ That part of the new synthesis shows some parallels to "old synthesis" Keynesianism (IS/LM etc.) and Monetarism, which also used mixes of the two approaches (see Section 3, and Leijonhufvud I981: I68). Yet, even the "sticky information « NNS remains based on the assumption of intertemporal general equilibrium, and hence excludes insights that may be gained from the analysis of disequilibria and temporary equilibria in older macroeconomics.

\subsection{Implications of Wicksell's concept of the natural rate of interest}

The notion of the natural rate of interest is central to Wicksell's theory of inflation. Two quotations from his Interest and Prices (1898) may suffice to demonstrate that this notion had a number of different meanings:

"There is a certain rate of interest on loans which is neutral in respect to commodity prices, and tends neither to raise nor to lower them. This is necessarily the same as the rate of interest which would be determined by supply and demand if no use were made of money and all lending were effected in the form of real capital goods. It comes to much the same thing to describe it as the current value of the natural rate of interest on capital [...]. It is thus confidently to be expected that the Bank rate, or more generally the money rate of interest, will always coincide eventually with the natural capital rate, or rather that it is always tending to coincide with an ever-changing natural rate.«(Wicksell I898: I02, II7; emphasis in the original)

I2 The Phelps-Festschrift (Aghion et al. 2003) that was co-edited by Woodford, and the contributions of Sims, Morris/Shin, and Mankiw/Reis in the AEA 2006 proceedings issue of the American Review (vol. 96, issue 2) attest to such attempts to model nominal rigidities by way of "sticky information«. For critique from different perspectives see Lucas (2003) and Leijonhufvud (2004). 
These definitions and predictions have at least five implications:

Implication I: barter equilibrium. The natural rate of interest is the market-clearing price in classical capital market equilibrium, which in "pure price theory « is conceptualized as the coordination of saving and investment plans in a barter economy. Since entrepreneurs (investors) and capitalists (savers) act in free competition (Wicksell I898: I03 - IO4, I34), this "real natural rate« is solely determined by the forces of productivity and thrift.

Implication 2: IS coordination. The natural rate of interest in a monetary economy is the equilibrium interest rate that coordinates planned investment (I) with planned saving $(S)$, free of current influences of monetary policy or the banking system. ${ }^{13}$

Implication 3: full employment. The natural rate is the interest rate at which the level of aggregate demand is sufficient to generate full employment and full capacity utilization. ${ }^{\text {I4 }}$

Implication 4: stable value of money. The natural rate is the interest rate at which the price level is stable - in modern parlance: the NAIRI (the non-accelerating-inflation rate of interest) at a zero inflation rate.

Implication 5: neutrality of money. The natural rate of interest is the attractor for the money rate of interest. The real value of the money rate (i.e. adjusted for inflation) is forced to converge on the natural rate, which implies that money (monetary policy) is neutral with respect to real variables, at least in the long run.

Wicksell's original notion of the natural rate was thoroughly criticized and redefined by Lindahl (1930), Myrdal (I93I) and Hayek (193I) - as well as Keynes (1936), whose contributions we relate separately, after summarizing the positions of the first three authors.

Lindahl (I930: 247 - 248) and Myrdal (I93I: 45 - 53) rejected implication I of Wicksell's natural-rate concept, demonstrating that the barter benchmark is useless for the analysis of a non-stationary monetary economy. Beyond simple one-good models or stationary economies in which the system of relative prices remains strictly fixed, the "real rate of interest " (in the sense of the expected rate of return on real investment) »cannot be regarded as existing independently of the loan rate of interest (Lindahl I930: 248).

Their refutation of implication I led Lindahl and Myrdal to refute implication 5. Unlike Wicksell (and Hayek), they rejected the notion of a long-run equilibrium that is purely determined by non-monetary fundamentals. Stressing the importance of expectations, they defined the "real interest factor« as

"the relation between anticipated future product values (with appropriate reductions for risk) and the values invested during the period " (Lindahl I930: 248, see also Myrdal I931: $32-34$ ).

I3 Since Wicksell (1898) discussed the evolution of banking systems at great length, one should add: "free of any influences $[\ldots]$ other than the banking system's general contribution to the reduction of transaction costs (economizing on the use of cash, monitoring services, etc.)."

I4 This implication does not follow directly from the quotations, but from the standard assumption of full employment in Wicksell (I898: 90, I43). 
The values invested depend on the demand for investment goods which is influenced by the loan rate of interest. Lindahl (1930: 249 , also I67) concluded »that the real rate of interest on capital $[\ldots]$ has a tendency to adjust itself to the actual loan rate of interest in every period «. He proved this point by constructing various scenarios of cumulative processes under imperfect foresight in which a lowering of the money rate of interest leads to a rise in the price level (Lindahl I930: ch. II). Inflation generates windfall profits which amount to "unintentional saving " to the extent that total saving adjusts to investment at the lowered money rate. However, Lindahl (1930: $180-183$ ) also stressed that the magnitude of the real effects of inflation is inversely related to the speed with which expectations adapt to the inflationary process, or even become forward-looking. In his framework, nominal rigidities play a role in determining the non-neutrality of monetary policy, but they tend to disappear in the course of the cumulative process, as both the formation of expectations and the stickiness of prices and wages are endogenous to inflation.

None of Wicksell's followers accepted implication 4 which equates the natural rate of interest with price-level stability. Hayek (I93I: 27) argued that the observation of price-level stability would not prove that the actual rate of interest is in line with the equilibrium rate (as he preferred to call Wicksell's »natural rate«). Since interest-rate gaps change the structure of prices and production, they lead to disproportionalities in the production of capital and consumer goods as compared to the savers' rate of time preference. The concomitant distortions of the price structure are not incompatible with price-level stability; the rate of inflation is not, at any rate, a reliable indicator of the inefficiencies caused by interest-rate gaps.

Lindahl and Myrdal, too, rejected Wicksell's implication 4, pointing out that changes in the "natural rate " which are due to changes in productivity induce inverse changes in the price level or otherwise start a cumulative process (Lindahl I930: ch.V, Myrdal I93I: ch.VI). They argued that, if Wicksell's "natural rate is reformulated in monetary terms, price-level stability is not a necessary condition of monetary equilibrium.

This leaves implication 2 to be explored. The named three authors essentially agreed with the definition of an equilibrium rate that coordinates planned saving and planned investment, independent of current influences of monetary policy or the banking system. Hayek (I93I: lect. II) stressed that the equilibrium rate must bring investment in »more roundabout processes of production " (i.e. increases in capital intensity that aim at increasing marginal productivity) in line with voluntary saving (i.e. the marginal rate of substitution between present and future consumption). Lindahl defined the "normal rate of interest « as neutral in the sense that it eliminates all excess demands for capital and consumption goods. It does not imply a constant price level, but "such a development of prices as is in accordance with the expectations of the public (Lindahl I93I: 252). Myrdal (I93I: ch. IV) had a two-component definition of the equilibrium rate of interest. Being the discount factor in the market for capital goods, this rate defines profitability. Equilibrium is attained if the difference between the present value of capital and its reproduction cost is zero. The same rate equates total investment with total »free disposal of capital«, i.e. saving in mon- 
etary terms plus »value change, defined as anticipated depreciation minus appreciation" (Myrdal I931: $82-84$ ).

Lindahl and Myrdal were nevertheless aware of a basic conundrum in the definition of a »normal« or »equilibrium rate of interest«: In order to serve as benchmark for the assessment of the effects of monetary policy, this rate has to be defined independently of monetary policy, even though it is co-determined by monetary policy. The conundrum can only be solved if the equilibrium rate of interest is defined as a path-dependent variable: The current equilibrium rate is influenced by past monetary policy (cf. Boianovsky/Trautwein 2006a).

In his Treatise on Money (1930), Keynes made extensive use of the Wicksellian notion of a natural rate of interest, mainly with regard to implication 2. In his General Theory (1936: I83 - I84, 242 - 244), Keynes fervently rejected all its implications but no. 3 (while being silent on no. 4). Investment is determined by the market rate of interest, which is essentially influenced by the liquidity preference of wealth-holders. Saving adjusts passively through the income mechanism, such that investment and saving are equal at different levels of interest, income and employment - an argument that was subsequently captured by the notion of the IS curve in the old neo-Classical Synthesis.

"If there is any such rate of interest, which is unique and significant, it must be the rate which we might term the neutral rate of interest, namely the natural rate [...] which is consistent with full employment." (Keynes 1936: 243 - emphasis in the original)

Our brief and incomplete review shows that Wicksell's concept of the natural rate of interest had been thoroughly scrutinized, criticized and redefined in the interwar literature. Given this critical background, one would expect modern macroeconomics in the NNS to use the concept with great care, basically dealing with two challenges. The first challenge is to solve the conundrum of defining an interest-rate benchmark for monetary policy in a world in which such policy is not neutral, neither in the short nor in the long run. The second challenge is to provide a rigorous and, at the same time, general foundation for the idea that the natural rate of interest should be identical with the NAIRI at (close to) zero inflation.

\subsection{Woodford's natural rate of interest}

Which of the five implications in Wicksell's natural rate of interest are present in Woodford's neo-Wicksellian concept? First of all, Woodford (2003: 248) states that "the natural rate of interest is just the real rate of interest required to keep aggregate demand equal at all times to the natural rate of output«. So it is »defined as the equilibrium real rate of return in the case of fully flexible prices (ibidem), a case for which Woodford finds that "equilibrium output is completely independent of monetary policy" (2003: $152-$ his emphasis). It is at the same time "the rate of interest required for an equilibrium with stable prices" (2003: $34 \mathrm{n} .22$ - emphasis in the original). Woodford demonstrates this by solving the AS and IS relations in Equations (2) and (I), under the assumption of zero inflation at all times. The result conforms Equation (I) taking »the form of a 'Fisher equation ‘ for the nominal inter- 
est rate, where the intertemporal marginal rate of substitution of the representative household plays the role of the real-interest factor" (2003: 7I).

The textual evidence suggests that Woodford would subscribe to implications 2, 3 and 4 of Wicksell's concept, but not to implications I (as if barter) and 5 (neutrality). Even though Woodford's baseline model of a cashless economy abstracts from all »monetary frictions «, it is not a barter model. The unit of account is defined in terms of a monetary asset, by which the central bank is held to control interest rates. ${ }^{15}$ This is also the reason why the nominal rate of interest would not automatically gravitate towards the nominal value of the natural rate: If prices are sticky, adjustments are not to be had without output gaps. Moreover, monetary policy is shown to have substantial and persistent real effects. In ch. 5 of his Interest and Prices, Woodford extends the neo-Wicksellian framework to include investment dynamics that change the capital stock and, hence, make the time path of the natural rate of interest an endogenous process. Here Woodford modifies his definitions of the natural rates of output and interest, now considering them

"as those that would result from price flexibility now and in the future, given all exogenous and predetermined state variables, including the economy's capital stock." (2003: 373 - our emphasis).

He thus implicitly acknowledges that the interest-rate benchmark for monetary policy is no longer independent of the policies chosen in the past. The latter affect the formation of the economy's capital stock through the extent, to which they allow inflation to make nominal rigidities effective. It seems as if he would allow for multiple short-run natural rates of interest here, depending on which time horizons are chosen for the evaluation of monetary policies, and the relationship with the long-run (steady state) natural rate of interest that is supposed to be given by the RBC core of the NNS model is not at all clear.

Price stickiness is thus the essential reason why Woodford does not subscribe to implication 5 , whereas he supports implication 4 (stable prices) in accordance with Wicksell (but not with Lindahl, Myrdal and Hayek). Woodford's concept of the natural rate of interest is compatible with implications 2 and 3 (IS coordination and full employment), but it is actually useless with respect to these defining characteristics of Wicksellian and Keynesian macroeconomics. The NNS framework is incapable of dealing with discrepancies between planned saving and investment and with involuntary unemployment, because it excludes both phenomena by assumption. Moreover, as the natural rates in the NNS also play the role of steady-state rates that provide the nexus in the integration of business cycle theory with growth theory, Woodford's position on implication 5 remains in a limbo. Going by the classical elements of the new synthesis, the natural rate of interest should work as an attractor for the short-run movements of the nominal interest rate. If the latter is, however, a political variable that can affect the economy's capital stock, the long run is not independ-

I5 Boianovsky and Trautwein (2006b) show, however, that the central bank does not control the nominal rate of interest in Woodford's baseline model of the cashless economy, due to the assumed existence of perfect substitutes for the central bank's liabilities. 
ent of the short, and the so-called »natural rate of interest « is not independent of the policy rates of the past. And since - in a model with forward-looking expectations of the private sector and interest-rate rules for monetary policy - the policy rates of the past are closely connected with those of the present, the old conundrum of what constitutes a neutral rate of interest turns out to be less tractable than ever.

\section{Conclusion}

Our comparative investigation of the NNS concepts of natural rates of output and interest, as represented by Woodford's canonical model, leads to rather critical conclusions. The concepts fulfil none of the typical functions of natural rates in an unambiguous fashion. Regardless of the empirical problems of measurement (which we have not addressed), Section 3 has shown that there are conceptual problems in making clear-cut distinctions between inefficient and efficiency-enhancing output gaps, where the latter would effectively reduce the welfare losses from the wedge between the competitive "flexible-price limit" and the (inefficient) natural rate of output under monopolistic competition. Even if the natural rate of output may serve as a reference for measuring gaps, it is not fully plausible as a normative target. The comparative examination of the implications of the natural rate of interest in Section 4 suggests that the RBC foundations of the NNS are at odds with the short-run dynamics in Woodford's investment model (2003: ch. 5), which may affect the capital stock and, hence, the steady-state rate of interest. This puts the normative role of the natural rate of interest in question, and it throws doubts on the indicative benchmark and attractor functions that it should have according to conventional understanding of a framework that integrates growth and business cycle theory on »intertemporal generalequilibrium foundations«.

Our paper has shown that the new synthesis is less encompassing than the labels »New Keynesian« and »neo-Wicksellian« suggest. Moreover, the comparison with older notions and criticisms of natural rates has exposed new trouble with such concepts. The »spanner in the works" approach of the NNS, which crucially relies on price stickiness in a quasi-monopolistic environment where households always are on their demand and supply curves, misses many of the deeper implications of the "incomplete information " approaches of older Wicksellian and Keynesian theories. The problems of coordinating the decisions of savers, wealth-holders, banks, firms and workers that were at the heart of those theories, are simply ruled out by three restrictions: intertemporal general equilibrium, rational expectations, and the absence of financial structure. Describing output dynamics as if the optimality condition of an individual plan and rational expectations would always keep output at optimal levels forestalls any inconsistencies between the decisions in the private sector. The absence of financial structure and liquidity preference - two market-inherent responses to problems of incomplete information - excludes the redistribution of income by way of inflationary creation of inside money, or by large-scale defaults in times of credit crises. Based on the assumption that financial markets are fully efficient and the observation that asset 
prices are very flexible (e.g., in Woodford 2003: 62, 44I), it has been generally concluded that large-scale changes in the level of asset prices are of no concern for monetary policy, as long as the level of goods prices can be kept stable. Restricted by its DSGE consensus, the NNS has failed to provide a framework that could have helped to anticipate and deal with the Great Credit Crisis which has developed recently at a global scale. It seems time to rediscover some of those essential insights of Wicksell, Keynes and their followers that have been eschewed by the New Neoclassical Synthesis. ${ }^{16}$

\section{References}

Aghion, P., Frydman, R., Stiglitz, J., Woodford, M. (eds.) (2003): Knowledge, Information, and Expectations in Modern Macroeconomics: In Honor of Edmund S. Phelps, Princeton: Princeton University Press.

Amato, J. (2005): The role of the Natural Rate of Interest in monetary policy, in: CESifo Studies, 5I, $729-755$.

Benigno, P., Woodford, M. (2005): Inflation stabilization and welfare: The case of a distorted steady state, in: Journal of the European Economic Association, 3, I185 - I236.

Blanchard, O., Galí, J. (2005): Real wage rigidities and the New Keynesian model, Working Paper presented at the FRB/JMCB conference on Quantitative Evidence on Price Determination, Washington, September, 29-30.

Boianovsky, M., Trautwein, H.-M. (2006a): Price expectations, capital accumulation and employment: Lindahl's macroeconomics from the I920s to the I950s, in: Cambridge Journal of Economics, 30, 88I - 900.

Boianovsky, M., Trautwein, H.-M. (2006b): Wicksell after Woodford, in: Journal for the History of Economic Thought, 28, I7I - I85 (also downloadable from Woodford's website at URL: www.columbia.edu/ $\sim$ mw2230/).

De Fiore, F., Tristani, O. (2008): Credit and the Natural Rate of Interest, European Central Bank Working Paper Series, No. 889.

Friedman, M. (1968): The role of monetary policy, in: American Economic Review, 58, I - 17.

Friedman, M., Schwartz, A.J. (1982), Monetary Trends in the United States and the United Kingdom. Their Relation to Income, Prices and Interest Rates, 1867 - 1975, Chicago: University of Chicago Press.

Goodfriend, M. (2002): Monetary policy in the New Neoclassical Synthesis: A primer, in: International Finance, 5, I65- I9I.

Hayek, F.A. (193I): Prices and Production, London: Routledge \& Kegan Paul.

Keynes, J.M. (1930): A Treatise on Money, 2 vols., London: Macmillan.

Keynes, J.M. (1936): The General Theory of Employment, Interest and Money, London: Macmillan.

I6 For a corresponding model of investment-saving imbalances in the spirit of Wicksell and Keynes, which is set in contrast to the standard NNS model, see Tamborini et al. (2008). 
Laubach, T., Williams, J. (2003): Measuring the Natural Rate of Interest, in: Review of Economics and Statistics, 85, 1063- 1070.

Leijonhufvud, A. (198I): The Wicksell Connection: Variations on a theme, in: Information and Coordination. Essays in Macroeconomic Theory, New York: Oxford University Press, $\mathrm{I} 3 \mathrm{I}-2 \mathrm{O} 2$.

Leijonhufvud, A. (2004): Celebrating Ned, in: Journal of Economic Literature, 42, 8II - 82I.

Lindahl, E. (1930): Penningpolitikens medel, Lund: Gleerups; quoted after English edition: The Interest Rate and the Price Level, Part II in Studies in the Theory of Money and Capital, London: Allen \& Unwin, I939.

Lucas, R.E. (2003): General comments on Part I, in: Aghion, P., Frydman, R., Stiglitz, J., Woodford, M. (eds.), Knowledge, Information, and Expectations in Modern Macroeconomics: In Honor of Edmund S. Phelps, Princeton: Princeton University Press, I37 - I4I.

Myrdal, G. (193I): Om penningteoretisk jämvikt. En studie över den «normala räntan« i Wicksells penninglära, in: Ekonomisk Tidskrift, 33, I9I - 302; quoted after English edition: Monetary Equilibrium, London: William Hodge, 1939.

Okun, A. (1962): Potential GNP: Its measurement and significance, in: Pechman, J. (ed.), Economics for Policymaking. Selected Essays of Arthur M. Okun, Cambridge, Mass.: MIT Press, 1983, I45- I59.

Patinkin, D. (1965): Money, Interest and Prices. An Integration of Monetary and Value Theory, $2^{\text {nd }}$ ed., New York: Harper \& Row.

Phelps, E. (1995): The origins and further development of the natural rate of unemployment, in: Cross, R. (ed.), The Natural Rate of Unemployment. Reflections on 25 years of the Hypothesis, Cambridge: Cambridge University Press, I5-3I.

Tamborini, R., Trautwein, H.-M., Mazzocchi, R. (2008): The two triangles: What did Wicksell and Keynes know about macroecononomics that modern economists do not (consider)?, Departments of Economics, Universities of Trento and Oldenburg, mimeo.

Tristani, O. (2007): Model misspecification, the equilibrium natural interest rate and the equity premium, European Central Bank Working Paper Series, No. 808 (September 2007).

van der Ploeg, F. (2005): Back to Keynes?, in: CESifo Economic Studies, 51, 777 - 822.

Weber, A., Lemke, W., Worms, A. (2008): How useful is the concept of the Natural Real Rate of Interest for monetary policy?, in: Cambridge Journal of Economics, 32, $49-63$.

Wicksell, K. (1898): Geldzins und Güterpreise. Eine Untersuchung über die den Tauschwert des Geldes bestimmenden Ursachen, Jena: Gustav Fischer; quoted after the English edition: Interest and Prices. A Study of the Causes Regulating the Value of Money, London: Macmillan, 1936.

Woodford, M. (2003): Interest and Prices. Foundations of a Theory of Monetary Policy, Princeton and Oxford: Princeton University Press.

Woodford, M. (2006): Comments on the symposium on "Interest and Prices", in: Journal of the History of Economic Thought, 28, I87- 198.

Woodford, M. (2009): Convergence in macroeconomics: Elements of the New Synthesis, in: American Economic Journal: Macroeconomics, I, $267-279$. 
